\title{
A.B. Simpson's Fourfold Gospel in the Evangelical Church of Vietnam: A Study of Selective Theological Assimilation'
}

\author{
NGUYEN Vinh Duy \\ Evangelical Church of Vietnam (South), Vietnam
}

\begin{abstract}
The officially distinctive mark of the Evangelical Church of Vietnam (ECVN) is the Fourfold Gospel emblem. It is inherited from A.B. Simpson, the founder of the Christian and Missionary Alliance (C\&MA), through the teaching of C\&MA missionaries in Vietnam. However, ECVN adapted some of the teachings and reinterpreted the symbols in the Vietnamese context. The reason is that the assimilation of the Fourfold Gospel to the ECVN's theology has been selective through a fundamentalistic perspective and a serious uneasiness about Pentecostalism, and hence, it has become disconnected from its original theological foundation.
\end{abstract}

\section{Keywords}

Evangelical Church of Vietnam (ECVN), Christian and Missionary Alliance (C\&MA), A.B. Simpson, Fourfold Gospel, sanctification, divine healing.

\section{The Evangelical Church of Vietnam AND A.B. Simpson's Fourfold Gospel}

The core message of the Evangelical Church of Vietnam (ECVN), ${ }^{2}$ the most established Protestant tradition in Vietnam, is the Fourfold

1 This article is based on Nguyen Vinh Duy, "The Fourfold Gospel of A.B. Simpson (1843-1919) in the theology of the Evangelical Church of Vietnam," (D.Th diss., Trinity Theological College, 2021).

2 The ECVN in this paper refers to the ECVN (South) and ECVN (North); the two churches have been organizationally distinct since 1954, but they share a history and a generally common theology. 
Gospel. It is represented in the emblem of the ECVN by a cross, a chalice, a pitcher, and a crown, which stand for salvation, sanctification, healing, and reward to the faithful, respectively. ${ }^{3}$ The Fourfold Gospel is rooted in the thought of A.B. Simpson (1843-1919), the founder of the Christian and Missionary Alliance (C\&MA), the missionary organization that planted the ECVN. Although the elements of the Fourfold Gospel—Christ Our Savior, Sanctifier, Healer and Coming King ${ }^{4}$ - were common in late nineteenthcentury American Evangelicalism, Simpson's theological innovation was in bringing together these prevalent christological themes of his time to form the Fourfold Gospel as a christocentric gestalt ${ }^{5}$ that brought together theological strands subsequently embraced by both fundamentalism ${ }^{6}$ and

3 ECVN, Nội Quy-Giáo Luật—Kỷ Luật (Regulations, Church Rules and Disciplines) (2002), 2 .

4 First laid out in Simpson, The Four-fold Gospel (New York: W.W.W Publishing, 1887; repr. 1890, 1925), a collection of four sermons on Christ Our Savior (Rv 7:10), Sanctifier (Jn 17:19), Healer (Mt 8:17; Heb 8:8), Coming Lord (Rv 2:28). For the attribution of the Fourfold Gospel to Simpson, see David Hartzfeld and Charles Nienkirchen, eds., The Birth of a Vision: Essays on the Ministry and Thought of Albert B. Simpson (Regina, Saskatchewan: His Dominion, 1986); Donald W. Dayton, Theological Roots of Pentecostalism (Grand Rapids, MI: Zondervan, 1987); Charles W. Nienkirchen, A.B. Simpson and the Pentecostal Movement (Peabody, MA: Hendrickson, 1992), among others.

5 Bernie A. Van de Walle, The Heart of the Gospel: A. B. Simpson, the Fourfold Gospel, and Late Nineteenth-Century Evangelical Theology (Eugene, OR: Wipf \& Stock, 2009).

6 Fundamentalism refers to "a broad coalition of evangelical Protestants who fought militantly against modernist or liberal theology" and subscribed to "the fundamentals of traditional supernaturalistic biblical Christianity" (New Dictionary of Theology: Historical and Systematic, 356, s.v. "Fundamentalism" by G. M. Marsden and J. D. Hankins, Jr.). Organizationally, the fundamentalist movement started with the formulation of the World Fundamental Christian Association (WFCA) in 1919 by William B. Riley. The term "fundamentalism" has its root in The Fundamentals, a widely circulated twelve-volume series of articles (1910-1915), defending the fundamental beliefs of the Christian faith, contributed by James Orr, B. B. Warfield, et al., and edited by A.C. Dixon, Louis Meyer, and R.A. Torrey. Torrey was also involved in the formulation of the WFCA; his theology remains influential among the fundamentalists as well as in the ECVN.

Theologically, fundamentalism is marked with dispensationalism and the Princeton Theology (R. Sandeen, The Roots of Fundamentalism [Ada, MI: Baker, 1970]). Also, fundamentalism is characterized by strong tendencies of separationism, individualism, the effort to return to "Bible alone," the stress on holiness, and the tension between anti-intellectualism and a commitment to scientific method influenced by Baconian philosophy and Scottish Common Sense Realism (George 
Pentecostalism. Simpson is considered a "proto-fundamentalist" who came through the Holiness movement and experienced "sanctification" before conversion to premillennialism. ${ }^{7}$ At the same time, he is seen as the forerunner of Pentecostalism, whose Fourfold Gospel is the antecedent of pentecostal theology, as noted by Donald Dayton. ${ }^{8}$

Although the Fourfold Gospel has been and still is the distinctive mark of both the C\&MA and the ECVN throughout their histories, ${ }^{9}$ the latter made significant modifications to it. This article is a study of that phenomenon. It argues that the ECVN's modification and interpretation of the Fourfold Gospel results from a selective theological assimilation through a fundamentalistic perspective and a serious uneasiness about Pentecostalism and, hence, has become disconnected from the original theological foundation of the Fourfold Gospel. We shall begin with a brief look into Simpson's Fourfold Gospel, followed by a brief historical account of its reception in the ECVN.

\section{A.B. Simpson AND THE Fourfold GOSPEL}

The Fourfold Gospel, the distinctive message of the C\&MA, was derived from Simpson's spiritual and theological journey under the impact of "providential movements" of the nineteenth century, according to George Pardington, the first C\&MA theologian and historian. These movements were (1) American revivalism from Charles G. Finney to D. L. Moody; (2) the Holiness movement represented by Finney and Methodist lay evangelists Phoebe and Walter Palmer; (3) the divine healing movement;

Marsden, Fundamentalism and American Culture, $2^{\text {nd }}$ ed., (New York: Oxford University Press, 2006). Most of these traits are seen in the development of the ECVN.

7 Gerald King, Disfellowshipped: Pentecostal Responses to Fundamentalism in the United States, 1906-1943 (Eugene, OR: Wipf \& Stock, 2011), 30-31.

8 Dayton, Theological Roots of Pentecostalism, 22, 175-176.

9 Robert Niklaus, John Sawin, and Samuel Stoesz, All for Jesus: God at Work in the Christian and Missionary Alliance over One Hundred Years, (Camp Hill, PA: Christian Publications, 1986). See also C\&MA's official website: http:/ / www.cmalliance.org. On the ECVN, see Phu Hoang Le, "A History of the Evangelical Church of Vietnam (1911-1965)" (PhD diss., New York University, 1972), 181. Le mistook "dove" for the "laver," since the "dove" is included in the emblem of the Foursquare movement, not that of the C\&MA. Note that the ECVN's current logo, however, has a "chalice" instead of "laver." 
(4) the revitalization of premillennial eschatology, and (5) the renewed interest in foreign missions. ${ }^{10}$ Specifically, Simpson's experiences of conversion, sanctification, divine healing, and conversion to dispensational premillennialism were influenced by those theological trends that he added on to his Puritan and Presbyterian background.

Simpson experienced personal conversion through his reading of Walter Marshall's The Gospel Mystery of Sanctification, ${ }^{11}$ which became the first aspect of his Fourfold Gospel, Christ Our Savior. Then, during his ministry in Louisville, he was deeply influenced by Boardman's The Higher of Christian Life ${ }^{12}$ and experienced "entire sanctification": the second aspect of the Fourfold Gospel. ${ }^{13}$ In 1881, Simpson's experience of divine healing through the ministry of Charles Cullis and his own Bible study led him to the third aspect of the Fourfold Gospel, Christ Our Healer. ${ }^{14}$ The last aspect of the Fourfold Gospel, Christ Our Coming Lord, resulted from Simpson's adoption of elements of dispensational premillennialism shortly after his experience of "entire sanctification." The sources of influence could be from James Brooks, ${ }^{15}$ a Presbyterian pastor in St. Louis during Simpson's term who participated in organizing the Niagara Prophecy Conferences (1880-1899), and from Simpson's attending the Believers' Meeting for Bible

10 George Pardington, Twenty-five Wonderful Years, 1889-1914: A Popular Sketch of the Christian and Missionary Alliance (New York: Christian Alliance, 1914), 13-17.

11 Walter Marshall, The Gospel Mystery of Sanctification, Opened, in Sundry Practical Directions: Suited Especially to the Case of Those Who Labor Under the Guilt and Power of Indwelling Sin (first published 1692; New York: Robert Carter \& Brothers, 1811).

12 William Boardman, The Higher of Christian Life (1858). Simpson, "A Personal Testimony," Alliance Weekly (hereafter AW) 45 (Oct. 2, 1915), 11; reprinted, AW (Nov. 1919), 98.

13 There is a debate on the date of and influence on Simpson's sanctification experience, after reading Boardman (Gerald E. McGraw, "The Doctrine of Sanctification in the Published Writings of Albert Benjamin Simpson” (PhD diss., New York University, 1986), or after D.W. Whittle's evangelistic campaign in 1874/1875 (Thompson, Life of A.B. Simpson (New York: Christian Alliance, 1920), 65-67; A.W. Tozer, Wingspread, (Harrisburg, PA: Christian Publications, 1943), 35-37. I follow McGraw (147-158), who carefully examines the dates given by Simpson's own accounts.

14 A.B. Simpson, Gospel of Healing (1915), 153-172.

15 Sung Kee Ho, "The Doctrine of the Second Advent of Jesus Christ in the Writings of Albert B. Simpson, with Special Reference to His Premillennialism” (PhD diss., Drew University, 1990), 63. 
Study of the Plymouth Brethren, who were influenced by John Darby's dispensationalism. ${ }^{16}$

The Fourfold Gospel could be summarized as follows. First, Christ is our Savior by reconciling humanity to God through his incarnation, obedience, atonement, and resurrection, thereby completely saving us from guilt, the wrath of God, inbred sin, an evil conscience, Satan's power, and eternal death, and giving us the divine nature "as a part of our very being" for now and eternity. One's salvation "is hinged upon his own choice and free will"17 to accept the reality of being "in Christ" rooted in the pactum salutis and thus to identify with Christ as the federal Head. ${ }^{18}$

Second, Christ is our Sanctifier by the Holy Spirit's indwelling of the sanctified believer to give power for the believer's holy living and service. Sanctification, also understood as the second aspect of a "double union" with Christ and as the baptism of the Spirit in the ordo salutis, is a "second blessing" subsequent to the first blessing of regeneration (a WesleyanHoliness view of sanctification). It is a definite work of God, marked by the believer's act of faith of separation from sin, dedication unto God, and conformity to God's will. Maintaining a Reformed doctrine of sin, Simpson rejected the Wesleyan teaching on the eradication of the sinful nature. But he was also dissatisfied with the Keswickian suppressionist view of sanctification, which, for him, "failed to emphasize the decisive nature of the experience." ${ }^{19}$ Simpson thus emphasizes sanctification as "habitation" : 20 "Christ Himself comes into the heart and lives His own life there," and "thus only can man enter completely into the life of holiness." ${ }^{21}$ Sanctification entails a transformation of the human nature into a divine nature, imparted by God and participated in by the believers.

16 Darrel Robert Reid, “'Jesus Only': The Early Life and Presbyterian Ministry of Albert Benjamin Simpson, 1843-1881” (PhD diss., Queen’s University, 1994), 348.

17 Simpson, The Four-fold Gospel (1890), 7-41 (hereafter FFG).

18 Simpson, "The Abiding Life," AW (March 27, 1915), 402; Simpson, Names of Jesus (1892), 81.

19 William Kostlevy, The A to Z to the Holiness Movement, $2^{\text {nd }}$ ed. (Lanham, MD: Scarecrow, 2010), 51.

20 McGraw, "The Doctrine of Sanctification."

21 Simpson, FFG, $42-47$ (62,65); Christ Life (1892) 27-52; The Name of Jesus (1892), 271279; Present Truth (1897), 53-58.. 
Third, Christ is our Healer by providing divine healing as part of his redemptive work and imparting "the life of Christ in our body" through a "tender union" with Christ. Divine health/healing, as an additional soteriological blessing and an earnest of the future resurrected body, flows from the person of the resurrected, living Christ. Thus, encountering Christ and abiding in union with him are essential for a proper appropriation of divine health/healing. Through union with Christ, divine healing is "the work of the Holy Spirit, quickening the body" of a believer who "recognizes the will of God, and bows to that in profound submission," acknowledging that sometimes "sickness has been allowed to come as a discipline." Furthermore, divine healing is about the "fullness of life until the life-work is done," which is "but the first-springing life of which the resurrection will be the full fruition." ${ }^{22}$ This eschatological vision qualifies the temporal and partial nature of divine health/healing in the here and now.

Fourth, Christ is our Coming Lord who is personally returning soon to receive the sanctified before the Tribulation before setting up the millennial kingdom. Thus, the climax of the Fourfold Gospel is perfect union with Christ, namely, the full realization of salvation, sanctification, and divine healing resulting from union with Christ. Christ's coming will bring us first "Jesus Himself," which is "the best of its blessings"; second, our "perfect spirits, restored to His image, glorious in His likeness" as well as our "perfect bodies"; and third, our "sweetest and highest service," "a perfect partnership in His kingdom and administration." 23

These four aspects of the Fourfold Gospel are bound together by the theme of union with Christ that secures the experience of salvation's full benefits and is informed by a partially realized eschatology that explains its temporal and partial nature. The benefits of full salvation are inextricably linked to Christ who is the substance of the believer's life, which Simpson terms "the Christ-life." ${ }^{24}$ The life and power of Christ are not simply given to the believer but communicated through this "actual union," and hence

22 Simpson, FFG, 75-109, 111-112.

23 Simpson, FFG, 110-152.

24 Simpson uses the term frequently in his writing; for example, he has three books entitled Christ Life, The Christ Life, The Christ Life and the Self Life. In "Editorial," The Christian Alliance and Foreign Missionary Weekly (October 2, 1895), 216, he contends that the C\&MA was a "Christ Movement" rather than a "Holiness movement." 
a "complete and continual dependence" 25 on Christ is essential for a true Christian life that Simpson believes to be the "deeper," "higher," "highest," "sweetest" life, the "highest possible standard" life. ${ }^{26}$ It is in this light that Christ is also to be understood as Divine Healer, who is the divine health of a believer in this life in anticipating the perfect union with Christ the Coming Lord. Although the Fourfold Gospel "sum[s] up in a very complete way the blessings which Christ has to offer us," ${ }^{27}$ the emphatic "Christ" is the focus, and union with Christ is the foundation of the this soteriology. On the basis of union with Christ, the believer partially enjoys these soteriological benefits in the here and now in anticipation of full realization in the eschaton.

However, two aspects of the Fourfold Gospel, together with their theological foundation, are not fully appropriated in the ECVN's reception of the Fourfold Gospel.

\section{The Fourfold Gospel IN THE TheOlOGY OF THE ECVN}

The ECVN received Simpson's Fourfold Gospel during a time of transition from Simpson to his successors under the impact of the fundamentalist-modernist controversy, the fundamentalist-pentecostal "disfellowship," and the influence of dispensational premillennialism in America. The C\&MA chose to prevent the impact of both modernism and Pentecostalism by siding with the World Fundamental Christian Association (WFCA), formed in 1919. The C\&MA's 1928 Doctrinal Statement combines the WFCA's nine Articles of Faith with "the distinctive Alliance testimony embodied in the Fourfold Gospel."28 Although two "distinctively" Simpsonian doctrines, Sanctification and Divine Healing, are preserved, ${ }^{29}$ this doctrinal statement thus marks the fundamentalist leanings of the C\&MA. However, to some fundamentalists and/or dispensationalists,

25 Simpson, The Christ in the Bible Series (Harrisburg, PA: Christian Publications, 1992), 4:404-405; 5:518.

26 "Editorial," The Christian and Missionary Alliance (March 31, 1900), 20.

27 Simpson, FFG (1925), 4.

28 Niklaus et al., All for Jesus, 229; See also Hans Hillerbrand, Encyclopaedia of Protestantism (Routledge, 2003), 1:653.

29 C\&MA, The Manual of the Christian and Missionary Alliance (1929), Articles of Faith 9 and 10. 
Simpson was criticized for "the extravagance" 30 of his Holiness theology and "the ancient heresy of a sentimental higher life." 31 This reservation about Simpson's Holiness theology is carried into the C\&MA's transmission of the Fourfold Gospel in the ECVN.

The theological development of the ECVN might be divided into four periods. ${ }^{32}$ First, the Implantation Period (1911-1927) demonstrates the ECVN's theology in its embryonic form through the work of C\&MA missionaries. Second, the Formulation Period (1927-1950) begins with the birth of the ECVN and ends with the ECVN's coming-of-age and adoption of the name Hội Thánh Tin Lành Việt Nam (literally, "The Sacred Society of Vietnamese Evangelicals") in 1950. Also, in the same year, Rev. Ong Van Huyen became the first indigenous chief editor of the ECVN's official periodical and Dean of the Bible School, and the ECVN's endorsed theological textbook was compiled by John Olsen. Third, the Transition Period (1950-1975) is marked with greater independence and growth of ECVN with the C\&MA as the advisor. The Bible school was upgraded to the Bible and Theology Institute (BTI) and started sending young leaders for theological education overseas. The ECVN became officially independent from the C\&MA in 1972, but it was the 1975 reunification of North and South Vietnam that marked the real independence of the ECVN from the C\&MA. Fourth, the Adaptation Period (1975-present) is also a period of testing and modifying the inheritance of Simpson and C\&MA theology that the ECVN had received.

$$
\text { Implantation (1911-1927) }
$$

The Fourfold Gospel in the Catechism

The Fourfold Gospel, except for its second aspect, Christ Our Sanctifier, was present in the C\&MA's catechism, Phước Âm Yếu Chỉ (Gospel Essentials), which was available in Vietnamese by late $1922 .{ }^{33}$ The catechism is a

30 B.B. Warfield, Perfectionism (1932), 2:556

31 Watchword 13 (1891), 60, cited in Sandeen, Roots of Fundamentalism, 177.

32 I owe a debt to Dr Le Hoang Phu's periodization in "A Short History of the Evangelical Church of Vietnam (1911-1965)," with modification and addition, in tracing ECVN's theological development up to present.

33 See R.M. Jackson's letter from Hai Phong to D.I. Jeffrey dated November 13, 1922: "I am teaching them Phuoc Am Yeu Chi." 
narrative of redemption history followed by teachings on the Christian life. The dispensational scheme $\mathrm{e}^{34}$ and the stress on holiness were unmistakable. The topics include (1) God; (2) the Bible; (3) Creation; (4) the Fall; (5) the Flood; (6) Abraham and the Jewish nation; (7) the Ten Commandments; (8) the Birth and Life of Jesus on earth;(9) The Second Coming of Jesus; (10) the Apostles; (11) the Atonement; (12) Jesus's Healing; (13) Angels, Heaven, and Hell; (14) The Holy Spirit; (15) Prayer; (16) Sabbath Rest; (17) the Church and Ordinances; (18) Idolatry, Ancestor Worship, Superstition; (19) Resurrection and Judgment; and (20) Exhortation.

The Fourfold Gospel vis-à-vis Fundamentalist Teaching

An embryonic Bible School was set up in 1919 by E.F. Irwin ${ }^{35}$ and officially launched in September 1921 by D.I. Jeffrey, a Presbyterian who graduated from Toronto Bible College, modelled after Moody's school. ${ }^{36}$ The curriculum of the Bible School in Vietnam was "somewhat modelled after that of Nyack [Missionary Training Institute]," ${ }^{37}$ which was "strictly a Bible course on the Old and New Testaments, Fundamental Doctrine, Christian Evidences, Missions, etc." The school's objective was to give students "a thorough Bible education and thus prepare them to preach the gospel of God's grace to the people, and to build up the Annamese Church in the great living truths of the Word of God." ${ }^{38}$

To distinguish the school from theological seminaries, the C\&MA missionaries insisted that it was a Bible school and not a theological school. ${ }^{39}$ The rationale was that "Bible School teaches: 'Thus saith the Lord,' [while] the theological school teaches about the 'Science of God' and

34 Cf. George W. Dollar, A History of Fundamentalism in America (Bob Jones University, 1973), 379: "The commonly taught dividing points of the dispensations are the Fall, the flood, the call of Abraham, the giving of the Law at Sinai, the Cross, the rapture of the Church, and the return of Christ."

35 C\&MA, AW (Jan. 1924), 741; John Sawin (C\&MA archivist and historian, former missionary to Vietnam), History of the Christian and Missionary in Vietnam,(manuscript, n.d., A.B. Simpson Historical Library), 186.

36 Dale S. Herendeen, "Undying Vision: A Sketch of the Life and Ministry of Rev. \& Mrs D.I. Jeffrey," The Call of Vietnam (Summer 1965), 4.

37 E.F. Irwin, With Christ in Indochina: The Story of Alliance Missions in French Indo-China and Eastern Siam (Harrisburg, PA: Christian Publications, 1937), 86.

38 Indochina Mission, Annual Report 1922, 19.

39 Cadman to Jeffrey, May 19, 1924 and July 12, 1924. 
in its moralizing and philosophizing creates 'modernism."'40 The school thus reflected fundamentalist characteristics demonstrated by the Bible Institutes in America, of which the C\&MA's school was one, if not the earliest. ${ }^{41}$

The content of Simpson's teaching transmitted to theological students was mainly devotional. In 1925, "Christ in the Bible" was included in the curriculum. ${ }^{42}$ The Christ in the Bible is a commentary series produced by Simpson (1888-1920) "t3 "to help the increasing number of consecrated Christians who are hungering for a deeper spiritual life and for a more profound acquaintance with the Word of God as it unfolds the fullness of Christ as Savior, Sanctifier, Healer and Coming Lord." ${ }^{4}$ Translated and printed works from this series include Christ in the Tabernacle, Joshua, Psalm, Romans, Acts, 1 \& 2 Corinthians, James, $1 \& 2$ Peter, 1,2\& 3 John, and Jude. ${ }^{45}$

Simpson's Wholly Sanctified was translated and published in French in 1924 (in Vietnamese in 1930). The idea of entire sanctification as holistic purity of the spirit, soul/mind, and body is more prominent in this book. Also in 1924, John Bunyan's Pilgrim Progress, which reflects the Reformed view of progressive sanctification, was translated by Olsen and printed in large quantities in its first edition. ${ }^{46}$ Highly regarded by Olsen and the C\&MA and well received by the masses,${ }^{47}$ it strongly emphasizes Holiness spirituality.

40 Cadman to Jeffrey, July 30, 1924.

41 Virginia Lieson Brereton, Training God's Army: The American Bible School, 1880-1940 (Bloomington, IN: Indiana University, 1990), 41-49.

42 Le, "A Short History," 133.

43 Simpson, The Christ in the Bible Commentary, 24 vols. (1888-1920); the modern printing (1994) is in six volumes (Camp Hill, PA: Christian Publications, 1992), hereafter cited as $C B C$.

44 Simpson, "Preface," Genesis, Exodus, 1888 edition, vii., cit. "Publisher's Introduction," $C B C$ vol 1.

45 John Sawin, "The Creation and Distribution of Christian Literature” (manuscript, 1982).

46 Quang Tac, Thiên Lộ Lịch Trình, (Hanoi: Imprimerie Evangélique, 1924). A.E. Snead (C\&MA Foreign Secretary), "Survey of Mission Fields of the Christian and Missionary Alliance, for the Year 1924, as Presented to Annual Council, May 27 to June 3, 1925," AW (June 27, 1925), 443, reports the first print of 3,000 copies of this book, while Simpson's book was only in 500 copies.

47 For instance, John Sawin, "The Creation and Distribution of Christian Literature" 
The influence of dispensationalists, especially R.A. Torrey, was more on doctrinal and systematic teaching. Torrey's What the Bible Teaches was among the training material for the Bible School from its early days. ${ }^{48}$ This work employs a biblicist approach to systematizing Christian doctrine in six books: (1) God, (2) Jesus Christ, (3) Holy Spirit, (4) Men, (5) Angels, and (6) Devils. Torrey's Practical and Perplexing Questions Answered, ${ }^{49}$ translated and adapted by W.C. Cadman, was published in 1924, entitled Thánh Giáo Biện $N g h i,{ }^{50}$ possibly the first theological textbook widely published in Vietnamese. It was recorded in 1953 that the pastors in some areas had to pass an exam based on this book. ${ }^{51}$ While the original version in English follows alphabetical order, the Vietnamese version arranges the content topically.

This book reflects a fundamentalist approach to holiness, which emphasizes purity and separation from worldliness and "apostate" churches such as Roman Catholicism. The emphasis on Holiness spirituality is unmistakable, including several commands prohibiting Christians from going to the theater, dancing, playing cards, and so forth. Torrey's doctrine of sanctification in this book is Keswickian. ${ }^{52}$

Torrey's teaching on divine healing in this book focuses on prayer for the sick according to James 5:14-15. Furthermore, although Torrey is sympathetic to Simpson's continuationism, he believes that spiritual

records a testimony given by a church member who was "marvellously delivered from insanity" that the book had been a blessing in his life.

48 D.I. Jeffrey, "Student Life in French Indochina," Call of French Indochina 5 (Oct.-Dec. 1923), 13; hereafter CFI.

49 R.A. Torrey, Practical and Perplexing Questions Answered (Chicago: Moody Press, 1908/9).

50 R.A. Torrey and W.C. Cadman, Thánh Giáo Biện Nghi (Sacred Religion Explained) (Hanoi: Imprimerie Evangelique, 1924); hereafter TGBN. Torrey's other works adapted and translated include Torrey's Topical Textbook (John Olsen, Kinh Tiết Sách Dẫn, 1952), and The Person and Work of the Holy Spirit (Đức Thánh Linh, 1969).

51 Gordon H. Smith, in his report from Ban Me Thuot, 1953, requested this book, for "native pastors must pass this test before they can be ordained." The content of the test is yet found. However, traditionally, the ECVN pastors pass doctrinal tests by giving correct answers based on required reading textbooks.

52 Torrey \& Cadman, TGBN, 26-27. 
miracles are timeless but that physical miracles are less frequent today because Christ is not physically present. ${ }^{53}$

The Emphasis on the Fourth Aspect of the Fourfold Gospel

The emphasis on the fourth aspect of the Fourfold Gospel for the cause of evangelism was intensified by key missionaries, especially R.A. Jaffray. In 1919, he "appealed for six new missionaries to be sent each year, . . . to finish the last great work of this dispensation and to accomplish the task that will usher in the Coming King." 54 The appeal clearly reflected the ethos of the C\&MA expressed in the fourth aspect of the Fourfold Gospel and Jaffray's strong dispensational premillennialism. Jaffray's Second Coming of Christ was among the very first of C\&MA's Vietnamese publications in 1924. ${ }^{55}$ This book left an impact on the Vietnamese, especially through Hoang Trong Thua, who "gave a series of messages on the Lord's second coming. . . . Thus he held the interest of a large audience and pointed many to the Lord Jesus." ${ }^{56}$

In summary, the missionaries transmitted Simpson's Fourfold Gospel with special emphasis on Christ Our Coming Lord as an impetus for evangelism and holiness. The transmission was underlined by a strong biblicism, separatism, and apocalypticism. These trends began to shape the theology of the embryonic ECVN.

Formulation (1927-1950)

The Fourfold Gospel in the Constitution (1927)

The emblem of the Fourfold Gospel was also the emblem of the ECVN but slightly modified. The Bible replaced "CMA" (see figure 1), which represents the ECVN's emphasis on the authority of the Scriptures. ${ }^{57}$

53 Torrey \& Cadman, TGBN, 48-49.

54 Sawin, History, 272.

55 R.A. Jaffray, Cưu Chúa Tái lâm khảo (Hanoi: Imprimerie Evangelique, 1924).

56 Jaffray’s Annual Report, AW (April 1919), 39, emphasis added.

57 Le, "A Short History," 181, did not mention the symbol of the Bible. However, a search through the ECVN archives shows that the emblem remains the same over the years with minor changes to the order of the four elements, and a chalice replacing the laver in the latest version (2001). 

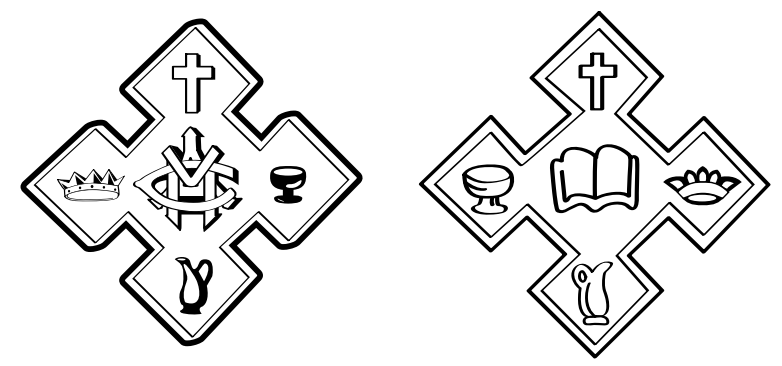

Figure 1: The emblems of C\&MA Missions in Vietnam and the ECVN, respectively.

The Fourfold Gospel was also found in the Articles of Faith, formulated in fifteen sections, which covered fundamental doctrines with extensive scriptural references as proof texts. ${ }^{58}$ However, the doctrine of sanctification was closer to the view articulated by Torrey than to Simpson's. It reflected sanctification as both instantaneous and progressive, but it omitted the language of "crisis" "subsequent to conversion" and attainable in this life. ${ }^{59}$ In this confession, the Holiness understanding of "entire sanctification" was implied in the phrase "free from the power of all sin," ${ }^{60}$ when the believer experiences instant sanctification (first level). "Wholly sanctified," understood as perfect sanctification, is the telos of progressive sanctification (second level). Furthermore, there is a stress on the Spirit's work in sanctification as well as on the believer's responsibility to seek sanctification by faith. Also, it implies a distinct faith and distinct reception of the Holy Spirit, which is found in Simpson.

However, it departed from Simpson's Christocentrism and his stress on sanctification as a distinct experience subsequent to regeneration, which was the Wesleyan-Holiness view. The confession seems to conflate the Reformed positional sanctification with Holiness experiential sanctification:

58 Constitution (1928), 20-24; (1936/1958), 26-32; (1963, North), 22-28; (1970, South, proposal), 52-57.

59 Constitution (1928), 22; (1936/1958), 29; (1963, North), 25-26, (1970, South, proposal), 54-55.

60 This resonates with Simpson (The Fullness of Christ [1886], 60), "sanctification is the deeper work which follows justification and deals directly with the inherent state of the heart with a view to its complete deliverance from the dominion and power of sin." 
(entire) sanctification is understood as positional sanctification (first level), which does not account for the believer's struggles with sins and the problem of falling during the "second level."

Nonetheless, the emphasis on holiness as separation and holy living was preeminent. A high view of holy living was required for being ECVN members, such as abstinence from drinking, smoking, gambling, and so forth. Thus, Holiness spirituality seemed to fit well with being culturally conservative, that is, the transformation from a bad life and unhealthy enjoyment as stated in Thánh Giáo Biện Nghi ${ }^{61}$ There was also a strong sense of separationism from worldliness, which also included intellectualism and materialism.

\section{The Fourfold Gospel in Literature and Hymnals}

The very first article of Bible Magazine ${ }^{62}$ expressed the "intention and mission" of the magazine as being to demonstrate Christ as Savior, Sanctifier, Healer and Coming One. It was immediately followed by Simpson's message on Christ as the only One who can satisfy humanity's needs. ${ }^{63}$ However, Simpson's writings, which appeared frequently in early issues of Bible Magazine, were mainly devotional. ${ }^{64}$ They appeared less frequently after 1940 and disappeared after 1954.

ECVN's hymn book, Thánh Ca [Sacred Songs], published in 1950, ${ }^{65}$ includes thirteen hymns selected from Simpson's corpus of 166 songs. ${ }^{66}$

61 Torrey and Cadman, TGBN, 56-58.

62 A monthly magazine published by the C\&MA-ECVN (1931-1975), first issue in January 1931, under the editorship of William Cadman, ceased during the World War II, and resumed in 1950 under the editorship of Ong Van Huyen. Vietnamese: Thánh Kinh Báo, later Thánh Kinh Nguyệt San. Hereafter TKB or TKNS.

63 Editor, "Soi tấm gương sáng” ("Following a Good Example”); A.B. Simpson, "Christ, Đấng làm thỏa lòng người” ("Christ, the One Who Satisfies Man’s Desire”), TKB 1 (Feb. 1931), 1-2, 3-6.

64 His more theological writings, published in the TKB after 1950, were "Himself" (No. 182, 1951, 39-40), Christian Life in the Four Gospels (Nos. 214-217, 220, 1954).

65 Its antecedents were Thơ Thánh [Sacred Poems], 1917, and Thơ Thánh có Nốt Đờn (Sacred Poems with Music Notes), 1930. The majority of hymns are translations of gospel songs from the Revivalist tradition, specifically, songs by the nineteenthcentury popular composers such as Fanny Crosby, Philip Bliss, D. Whittle, et al., and Holiness composers such as Charles Wesley and Phoebe Palmer, besides songs composed by Simpson, C\&MA missionaries, and ECVN’s leaders.

66 Eugene Rivard, "Rediscovering the Music of A.B. Simpson," in Hartzfeld \& 
These hymns cover main features of his theology: Jesus Only (The Fourfold Gospel), Come and Take (Salvation), Himself; Launch Out; Step by Step; Be True (Sanctification), Yesterday, Today, and Forever; Stretch Forth Thy Hand; Nothing Is Too Hard for Jesus (Healing), Some Sweet Morn; No More Sorrow (Coming King); Go and Tell; A Hundred Thousand Souls a Day (or A Missionary Cry) (Mission). ${ }^{67}$

However, hymnal texts written by ECVN's leaders such as Phan Dinh Lieu (an early leader of the ECVN), Le Dinh Tuoi (the fourth president of the ECVN), Ong Van Huyen (the first indigenous dean of the Bible School and editor of Bible Magazine), and Nguyen Van Van (former editor of Bible Magazine) highlight the first and fourth aspects of the Fourfold Gospel (Salvation and Second Coming) with emphases on sin, grace, salvation, mission and Christ's return. ${ }^{68}$ As such, Vietnamese hymn composers reflect a form of experiential, revivalist, pietistic evangelicalism that focuses on salvation and evangelism.

The Fourfold Gospel in John Olsen's Theological Textbook

John Olsen (1893-1954) designed the curriculum of the Bible School and solidified the theology of ECVN through his teaching and theological textbook Thân Đạo Học [Theological Study] (1950/1958). ${ }^{69}$ This book takes a biblicist, doctrinal approach to systematic theology; different views are presented briefly, with no footnotes, to be refuted in favor of a certain view considered as "orthodox." It set the standard for ECVN theology and deeply influenced the theology of ECVN pastors and leaders for many

Nienkirchen, eds., The Birth of a Vision (1986), 77.

67 Hymns 156, 179, 227, 223, $291 \&$ 464, 453 \& 484, 77, 247, 284, 331, 125, 360, 350, respectively.

68 For instance, Phan Dinh Lieu's hymns tell the gospel story (two hymns on Christ's birth, hymns 68 and 69), stress Faith, Hope, and Love (hymn 310), and exhort believers to Tell the Good News (hymns 329/473), contending that it is the Only Mandate (hymn 352) of Christians. Le Dinh Tuoi's five hymns focus on the sacrificial love of Christ and the urgency of salvation due to the shortness of life, and a call for mission work in the highlands. Ong Van Huyen rejoices that Asia has received God's grace (hymn 320), expresses gratitude to God's grace (hymn 409) and concerns for many who are under the power of Satan (hymn 353), and commitment to the responsibility of evangelism (hymn 353). Nguyen Van Van's Holy Communion (hymn 400) expresses a commitment to evangelism and longing for Christ's return to "end this sinful and suffering life."

69 John Olsen, Thân Đạo Học (Gospel Press, 1958). Hereafter TĐH. 
generations. It remains the only authorized theological textbook for the ECVN to this day. ${ }^{70}$

A comparison reveals that Olsen's textbook closely followed George Pardington's Outline Studies in Christian Doctrine ${ }^{71}$ in both outline and content, with minor changes and adaptation. ${ }^{72}$ Like Pardington's work, Olsen's system includes ten loci framed by bibliology and dispensational eschatology. A close look at Olsen's work shows that the materials were mostly from A.H. Strong's Systematic Theology ${ }^{73}$ (Pardington himself heavily borrowed from A.H. Strong $)^{74}$ and some from Jia Yu-ming, a Chinese fundamentalist. ${ }^{75}$

Although Simpson's Fourfold Gospel is not formally incorporated into Olsen's systematic theology, Olsen follows much of Simpson's teaching on sanctification. Especially, Simpson's teaching on Christ's indwelling as the nature of sanctification was preserved: "sanctification is Christ's life in us." ${ }^{\prime 6}$ Furthermore, Olsen agreed with Simpson's ordo salutis that Christ's indwelling (the second aspect of union with Christ) and baptism of the Holy Spirit are listed together as the experience of sanctification. ${ }^{77}$

70 This work was endorsed by Rev. Ong Van Huyen, the first indigenous dean of the Bible School and former president of the ECVN, and remains the standard, according to the current principal of the Institute of Bible and Theology and president of the ECVN, Rev. Thai Phuoc Truong.

71 George Pardington, Outline Studies in Christian Doctrine (New York: Christian Publications, 1916).

72 Olsen adds soteriology, which is absent in Pardington's book, and moved Angelology to the later part of his work.

73 Olsen explicitly mentions Strong around ten times, and a comparison reveals that he used Strong's Systematic Theology, 1907 edition. But Strong's influence can be detected all over Olsen's work, as observed by Philip Trinh, K. V., "Toward a Doctrine of Sin in the Vietnamese Context: Elements in the Dialogue between Vietnamese Indigenous Perceptions and Christian Teaching on Sin by Missionaries" (Ph.D. diss., Graduate Theological Union, 2004), 110-111.

74 Pardington (1916) approvingly cites Strong around 117 times.

75 Jia Yu-ming, 神道学, (Nanking Theological Seminary, 1921). Lieu Dinh Phan, "Chứng thực quyền Chúa" (Testimony of God’s Power), manuscript, 1969, reprinted in Thai Van Le, Bốn mươi sáu năm trong chức vu [Forty-six Years in Ministry] (Saigon: Gospel Press,1970), 102, recounts that he "translated the Thân Đạo Học from Chinese to Vietnamese for Dean Olsen." Certain parts in Olsen, for instance, his arguments for God and God alone (104-114), closely follow Jia (95-104, 1967 edition).

Olsen, $\mathrm{T} \bigoplus \mathrm{H}, 704$

77 Simpson, Present Truth (1897), 50-51; Olsen, TĐH, 708. 
In addition, Olsen followed Simpson to distinguish between receiving the Holy Spirit for regeneration and for sanctification, ${ }^{78}$ and he utilized the two-step soteriological paradigm to explain the reason for non-sanctified believers' failure and the need for experiential sanctification: "a believer ... only knows Christ as his Savior but has not known Christ as Sanctifier" and thus "stands in the holy position of Christ [but] has not yet had Christ's indwelling in him."

However, in an attempt to fit Simpson's teaching within Strong's Reformed framework of sanctification, Olsen articulated that experiential sanctification is definite and progressive, achieved in three stages: First, entire sanctification, also called baptism in the Holy Spirit, is instant. It is a "reckoning" by faith of the state of "being wholly sanctified in Christ" given by God on account of Christ's finished work, and thus distinguished from positional sanctification at regeneration. ${ }^{80}$ Second, progressive sanctification or Christian maturity is to be achieved day by day in walking with the Spirit. Third, perfected sanctification is achieved only when Christ returns and every believer shall see him and be like him, according to $1 \mathrm{Jn}$ 3:2. At that time the power of the triune God will transcend all the elements of the self of a believer. ${ }^{81}$

Olsen thus implied, with Simpson, that "entire sanctification" (understood as "instant sanctification") can be achieved, that is, reckoned by faith, in this life, ${ }^{82}$ as the beginning of the way to perfect sanctification through progressive sanctification. This understanding of "entire sanctification," however, is not aligned with ECVN's view articulated in its ecclesiastical literature.

78 Olsen, $\mathrm{TÐH,} \mathrm{575,} \mathrm{705-709.}$

79 Olsen, $\mathrm{T} \bigoplus \mathrm{H}, 689$, the only instance Olsen mentions Christ as Sanctifier.

80 Olsen, $\mathrm{T} H \mathrm{H}, 711$.

81 Olsen, $\mathrm{T} \bigoplus \mathrm{H}$, 711-713.

82 This aspect is also retained in Pardington $(1916,186)$, who rejects the "old extreme Calvinistic view of sanctification ... that death alone can free us from sin." 


\section{Transition (1950-1975)}

The Fourfold Gospel in the Revised Constitution

In the 1970 General Assembly, ECVN leaders, led by the then principal of BTI and ECVN vice-president Ong Van Huyen, proposed a revision of Constitution and Regulations. ${ }^{83}$ While the "cardinal doctrines" of the Fourfold Gospel formula remained intact, an interpretation of the Fourfold Gospel was introduced. The square cross in the emblem stands for salvation for the people from four corners of the world, and the four elements of the Fourfold Gospel, symbolized by a cross, a bronze chalice, a pitcher, and a crown, respectively, refer to soteriological blessings, namely, salvation, sanctification, healing, and millennial reward.$^{84}$ This interpretation is thus anthropocentric rather than christocentric. Furthermore, the second element in the emblem was explained as a "bronze chalice" instead of "laver," to connect it with Holy Communion and the blood of Christ as the means of ongoing sanctification. The change could be intentional or accidental, since the laver and bronze cup symbols look alike. Nonetheless, this interpretation diverges from Simpson's idea of Christ as the Sanctifier with the Holy Spirit.

The rationale for this interpretation of the Fourfold Gospel has yet to be found, ${ }^{85}$ but it reflects either neglect or a recontextualization of the historic Simpsonian Fourfold Gospel. This modification could derive from the ECVN's historical-ecclesiastical context, in which the urgency of evangelism is driven by dispensational premillennialism, uneasiness about the influence of Pentecostalism, and the desire to uphold revivalism.

\section{Revivalism without "Pentecostalism"}

In 1971-1972, revivals broke out in the BTI, catalyzed by a course on "History of Revivalism" and missionaries who returned from training at

83 ECVN, Dư Án Hiến Chương của Hội Thánh Tin Lành Việt Nam (Proposed Revised Constitution of the ECVN), 1970.

84 ECVN, Dự Án Hiến Chương (1970), 17-18.

85 A distant interview with Rev. Ho Xuan Phong (Oct. 6, 2019), the only survivor among the Constitution Revision Committee, did not yield clear answers of the rationale behind this interpretation. According to Rev. Ho, this Revised Constitution was discussed in General Assemblies between 1971 and 1974, but it could not be ratified due to disagreements on policies rather than doctrines. 
Fuller Seminary, as documented by Steinkamp, ${ }^{86}$ a lecturer at BTI, and also by ECVN leaders. ${ }^{87}$ There were disorderly cries of repentance, testimonies of divine healing, but no record of glossolalia in the revival.

The ECVN responded cautiously against the abuse of glossolalia. A translation of the "Seek Not-Forbid Not" document (from the C\&MA Conference on April 24, 1963) appears in the Bible Magazine in March 1971. ${ }^{88}$ In 1973, articles in ECVN's Bible Magazine warned against glossolalia, ${ }^{89}$ stressing that revivalists John Sung and Billy Graham as well as many Christian saints through the ages, such as Calvin, Knox, Wesley, Carey, Judson, Taylor, Moody, Spurgeon, Torrey, and Sunday never spoke in tongues..$^{90}$ The ECVN previously encountered a tongue-speaking sect in 1942, when it had to reject a group (called the "Banana Coconut Society") who wished to join the ECVN as Christian believers. ${ }^{91}$ The fact that this group "spoke in tongues" before learning of Christianity and attempting to join the ECVN solidified the C\&MA/ECVN's belief that tongues may not necessarily come from the Holy Spirit and reinforced their practical avoidance of tongue-speaking.

\section{Adaptation (1975-Present)}

\section{Theological Education}

The teaching and writings of spiritual leaders of the ECVN, such as Rev. Doan Van Mieng and Pham Xuan Tin, provided an important source for sustaining the doctrinal/theological learning of the ECVN. Doan's theology is a mixture of Simpson/Olsen and Reformed theology, which

86 O. Steinkamp, The Holy Spirit in Vietnam (Illinois: Creation House, 1973).

87 ECVN, Việc của Đức Giê-hô-va: Cuộc phấn huing tại Nam Thượng Hạt [The Lord's Work: Revival in the Upper Southern District] (Saigon: Tin Lanh), 1971; ECVN, "Lửa Thánh Linh bùng cháy tại Thần-Học-Viện" "'The Spirit's Fire Is Aflame at the Bible and Theology Institute"), TKB 395 (May 1972), 25-26; C\&MA, "Revival at Nha Trang Bible Institute," Vietnam Today (Summer 1972), 8-9.

88 TKNS 383 (Feb.-Mar. 1971), 8-12, 39-40. See also Paul L. King, "Seek Not, Forbid Not: The Early Christian and Missionary Alliance Position on Glossolalia," Wesleyan Theological Journal 40, no. 2 (Fall 2001): 84-219.

89 TKNS 408-410 (1973).

90 TKNS 409 (Oct 1973), 3.

91 D.I. Jeffrey, "Church Growth in Vietnam," manuscript (1963), 19. 
could have been obtained through his own study. For instance, in Basic Doctrines, ${ }^{92}$ he incorporated part of Simpson's understanding of “entire sanctification" with a Reformed doctrine of sanctification: Sanctification involves, first, "liturgical or positional sanctification," which immediately follows regeneration ("a regenerated person is reckoned as holy person instantly and immediately. God addresses all believers as saints because we are set aside to belong to Him, to stand in Christ's position"), and second, "moral or experiential sanctification," which "is entire sanctification: spirit, soul and body (1 Thes 5:23)." ${ }^{\prime \prime 3}$ Sanctification in the Christian life is to be "entire" in the sense that spirit, mind, and body must be holy. Entire sanctification is thus conflated with progressive sanctification and is applied only to the future. Simpson's teaching of "entire sanctification" as a second work of grace is absent in Doan's.

Although Simpson's The Holy Spirit ${ }^{94}$ is still in the required reading list for ordination, ${ }^{95}$ the ECVN's understanding of baptism of the Holy Spirit is in alignment with the Reformed, dispensationalists, and most Baptists that Spirit baptism occurs simultaneously with regeneration. ${ }^{96}$ It is silent on Simpson's understanding of baptism of the Spirit for sanctification as a second blessing. Instead, the ECVN has "spirit-filling" as repeatable blessings subsequent to conversion/sanctification for power for service rather than sanctification. ${ }^{97}$

Simpson's Holiness theology is further neglected and forgotten because of the same pattern experienced by the C\&MA in the early twentieth century: a conflict with and distance from the charismatic movement (which formed a subgroup within Vietnamese Evangelicalism).

92 Doan, Giáo Lý Căn Bản, n.d., n.p., a teaching manual that consists of thirty-nine lessons and covers basic doctrines of God, Christology, pneumatology, and soteriology.

93 Doan, Giáo Lý Căn Bản, lessons 36-37, n.p.

94 A.B. Simpson, Luận Về Đức Thánh Linh, trans. from The Holy Spirit or Power from on High (Saigon: Gospel Press, 1959).

95 ECVN, Giáo Nghi (Church Liturgy) (2008), 89-90.

96 ECVN, Catechism (2011), 21.

97 ECVN, Catechism (2011), 22. 


\section{Response to the Charismatic Movement}

The charismatic movement in Vietnam started in the 1980s, when some charismatic ECVN pastors drew to themselves large numbers of ECVN members. ${ }^{98}$ This created ecclesiastical problems and led to further cautiousness and suppression of pentecostal-related issues in the ECVN. The ECVN's leaders released documents to make clear its stand and to distance itself from Pentecostalism. Theoretically, the "seek not-forbid not" policy inherited from the C\&MA was taught; the ECVN only warned against the abuse of charismata, including glossolalia ${ }^{99}$ In reality, the ECVN took a strong stand against tongue-speaking, and several charismatic leaders chose to withdraw to found new churches, usually with former ECVN members.

The ECVN's Letter of Notice 21/TLH/VP dated 24/06/1989 ${ }^{100}$ and signed by Rev. Ong Van Huyen, the then-president of the Southern ECVN, warned the church of a "weird phenomenon," namely, "excessive speaking and praying in tongues." It repeated the same arguments in the abovementioned Bible Magazine articles on tongues speaking in 1973. ${ }^{101}$ The letter also noted that the phenomenon had been worsened by the accompaniment of reportedly charismatic abuse, the performing of miracles and destruction of dragon images (which could have been influenced by the Third Wave movement). This experience has intensified the ECVN's caution against pentecostal and charismatic expressions, reflected in the 2001 Articles of Faith's warning against the abuse of tongues speaking and healing miracles.

The Fourfold Gospel in the Constitution 2001

In 2001, when the revised Constitution was ratified in 2001 General Assembly, ${ }^{102}$ the 1970 interpretation of the Fourfold Gospel was adopted and amended as follows: First, the Cross stands for "salvation that comes

98 See Vince Le, “The Pentecostal Movement in Vietnam," in Global Renewal Christianity: Asia and Oceania Spirit-Empowered Movements: Past, Present, and Future, ed. Vinson Synan and Amos Yong (Lake Mary, FL: Charisma House, 2015), 181-195.

99 ECVN, TKNS 383 (Jan.-Feb. 1971), 8-12, 39-40.

100 Retyped in Son Thai Tran, Sau Hai Mươi Năm (After Twenty Years), (manuscript, 1995), n.p.

101 ECVN, TKB, no. 408-410 (1973).

102 ECVN (South), Hiến Chương (Constitution) (Hanoi: Religious Publisher, 2002). 
from the death of the Lord Jesus Christ on the cross." Second, the Crown symbolizes "the reward for every faithful believer on the day the Lord Jesus Christ returns so that he/she will be co-sovereign with the Lord." Third, the Pitcher means "every believer by faith in the Lord Jesus Christ and the power of the Holy Spirit is healed from sickness and strengthened." And fourth, the Chalice refers to the fact that "every believer by the blood of the Lord Jesus Christ is cleansed of sins and sanctified." ${ }^{103}$ As mentioned above, this interpretation is anthropocentric and disconnected from Simpson's foundational emphasis on union with Christ.

Significant changes in the Articles of Faith, formulated in twenty-one sections, includes: first, a separate doctrine of sanctification is no longer listed; regeneration and renewal are mentioned under the article of Salvation (article 61). In other words, though sanctification is one aspect of the Fourfold Gospel, this doctrine is no longer seen as a distinctive to be listed separately in its Articles of Faith. The ECVN holds the Reformed view in sanctification, ${ }^{104}$ in which the language of "entire sanctification" is preserved but only in futuristic terms. ${ }^{105}$

Second, divine healing is to be considered merely a Spirit gift and listed together with the doctrine concerning the gift of tongues speaking (article 65). The teaching of divine healing in the atonement and its Christocentrism is muted. The focus is the gift of healing and prayer for the sick as taught in James, which was not included in the previous Articles

103 ECVN, Nôi Quy-Giáo Luật—Kỷ Luật (2002), 2.

104 ECVN, Basic Biblical Training, Year 2 (teacher's manual), 88-94, citing Louis Berkhof for support. Progressive sanctification is implied in Constitution (2001), 50; Catechism (2011), 36-37, using the terms of "renewal." Besides the view articulated in the Constitution 1927 and Olsen's textbook, there seems to be a long-time teaching of the Reformed view of sanctification in the ECVN on the popular level. For instance, Huynh Van Nga, Dẫn dân quy đạo (Leading People to Conversion) $(1937,36)$, mentions a Reformed doctrine of sanctification. It could be that the Reformed view becomes dominant because of the impact of the ECVN leaders and seminary lecturers who were sent to and came back from Reformed-inclined institutes: Wheaton College, Moore College, and Gordon-Conwell Seminary. Pham Xuan Tin, Systematic Theology, vol. IV, (n.d., n.p.), 287-288, and vol. V (n.d., n.p.), 198-201, teaches a doctrine of sanctification that includes positional, experiential, and complete sanctification. As mentioned, Doan Van Mieng in his Basic Doctrines also teaches a Reformed doctrine of sanctification in which entire sanctification is applied as the telos of progressive sanctification.

105 ECVN, Basic Biblical Training, Year 2 (teacher's manual), 92-94. 
of Faith (1927-1970s). Third, doctrines on charismata (articles 64-65) were added to define the gifts of the Holy Spirit and warn against the abuse of gifts. Glossolalia was among the limited gifts, based on 1 Corinthians 13:8. The ECVN thus adopted a position of soft cessationism. These changes, as seen in the current teachings in the ECVN, show that the ECVN has distanced itself from the Holiness teaching of Simpson, whose views on sanctification and divine healing are apparently close to Pentecostalism.

\section{Summary and Conclusion}

Historically, the transmission of Simpson's theology in the ECVN was filtered through a fundamentalist lens of the C\&MA missionaries and hence selective, resulting in an incomplete reception of Simpson's Holiness theology, as reflected in the ECVN's ecclesiastical writings and its reinterpretation of the Fourfold Gospel formula.

Dispensational eschatology was well received in the very beginning of the ECVN, partly due to the sociopolitical upheavals of the time that made sense of the belief in an imminent Return. This teaching on eschatology aligned with the last aspect of the Fourfold Gospel and was closely linked with the success of evangelism, a manifestation of Christ Our Savior. Hence, the reception of the first and last aspects of the Fourfold Gospel, Christ Our Savior and Christ Our Coming King, was the strongest. In the early stage, the third aspect, Christ Our Healer was also received solidly, partly for evangelistic purposes. Healing in the atonement was taught in the Catechism (ca. 1922) and included in the Articles of Faith (Constitution 1927). However, the theology of Christ the Healer is underdeveloped. Simpson's inclusion of divine healing in soteriology is not integrated into Olsen's and ECVN's theology. Today, the practice of anointing of the sick with oil remains, but divine healing is placed under pneumatology as a spiritual gift to be used with caution. ${ }^{106}$

The second aspect of Simpson's Fourfold Gospel, Christ Our Sanctifier, enjoyed the least reception, despite the fact that holy living has been ECVN's hallmark since its inception, and holiness would be the last thing to be neglected by the fundamentalist-dispensationalists. In its early history, the ECVN was ready for the reception of holiness understood as moralism, separationism, pietism, activism, and fleeing from materialism.

106 ECVN, Constitution (2002), article 65. 
But Simpson's theology of Christ Our Sanctifier was not mentioned in the Catechism. The doctrine of sanctification listed in the Articles of Faith (1927) adopted the view articulated by Torrey translated and edited by Cadman. Although Simpson's doctrine of sanctification is appropriated in Olsen's theology, Simpson's emphasis on the indwelling of Christ in union with the believer by the Spirit was perhaps too "Pentecostal" or "mystical" to the then C\&MA missionaries and ECVN leaders.

Since 1970, the ECVN has interpreted the Fourfold Gospel formula in a way that accentuates the four soteriological blessings: salvation, sanctification, healing, and rewards from the Coming King to the faithful in purity and evangelism. This interpretation, however, reflects a departure from Simpson's christocentric soteriological gestalt underpinned by a strong foundation in union with Christ and framed by an eschatology that envisions the partial realization of salvation in the present; lacking its foundation and framework, the Fourfold Gospel is perceived as a collection of soteriological blessings.

The ECVN's interpretation of the Fourfold Gospel could be an adaptation of Simpson's theology under the ECVN's historical-ecclesial context: the urgency and priority of evangelism driven by dispensational premillennialism and the caution to distance itself from Pentecostalism while upholding revivalism for the cause of evangelism. The prominence of evangelism in ECVN's self-understanding of its raison d'être in view of premillennial eschatology, injected by the C\&MA, impacted by fundamentalist evangelicalism, and intensified by the context of suffering and life fragility due to wars and poverty (as seen in Le Dinh Tuoi's hymn, "Human Life Is Short"), has resulted in ECVN's focus on soul-saving as the only mandate of the church, and its byproduct, a spirituality with a false dichotomy of body and soul. Furthermore, the ECVN desires revivalism without Pentecostalism, due to the C\&MA's and ECVN's experiences with pentecostal and charismatic movements in the early twentieth century and in the 1970s-1980s. The ECVN's caution to distance itself from Pentecostalism, however, has neglected its roots in Simpson's Holiness theology, which may have implications for ECVN's revivalism. Without an adequate theological foundation of holiness, revivalism can be humanistic and legalistic. 
Another reason for the selective assimilation of Simpson's theology could be that his folk theology was not adequately grasped and transmitted by the C\&MA missionaries. Simpson was not a theologian and did not articulate his theology systematically and concisely. The missionaries and ECVN leaders could receive Simpson's revivalism, pietism, divine healing, and elements of dispensational premillennialism through a fundamentalist lens. Indeed, the ECVN did not fully receive Simpson's Fourfold Gospel theology with the latter's inherent foundations and framework.

Although Simpson's theology, arising from the context of the nineteenth-century Holiness movement, was not without weaknesses and flaws, a critical reappropriation of his Fourfold Gospel in connection with its theological foundation will strengthen ECVN's theology of salvation and the Christian life by rooting it in union with Christ. In a religiously pluralistic context that is expected to see the church as the "holy society" of the true God as it claims to be and relevant to society, a rediscovery of Simpson's concern for "full salvation" behind the Fourfold Gospel has the potential of supplying theological resources for the development of a more robust theology of salvation and Christian life for the ECVN within its own theological heritage.

\section{About author}

NGUYEN Vinh Duy, DTh (Trinity Theological College, Singapore), is currently a pastor with the Evangelical Church of Vietnam (South). 